\title{
The Spatial Analysis of Female Voters' Behavior
}

\author{
Adji Suradji Muhammad ${ }^{1, *}$, Gusrizal ${ }^{2, *}$, Pery Rahedra Sucipta ${ }^{1}$, Rodi Wahyudi ${ }^{3}$, Misni $^{4}$ \\ suradji@umrah.ac.id, gusrizal@sm-performa.co.id² \\ ${ }^{1}$ Universitas Maritim Raja Ali Haji, Tanjungpinang, ${ }^{2}$ Sinergi Multi Performa Consultant, \\ Tanjungpinang, ${ }^{3}$ Universitas Islam Sultan Syarif Kasim, Pekanbaru. ${ }^{4}$ Women's and Children's \\ Empowerment Agency, Province of Riau Archipelago (Kepulauan Riau)
}

\begin{abstract}
The purpose of this study is to find out what factors influence the behavior of female voters. This study was carried out in the city of Tanjungpinang, Riau Archipelago (Kepulauan Riau) Province, Indonesia. A number of questionnaires were distributed to obtain female voters' perspective related to the $2014^{\text {th }}$ legislative election. Spatial visualization showed that two factors competed to dominate the behavior of female voters, namely ideology similarity and candidate's religiosity. The results of spatial analysis based on Global Moran's $I$ and Local Indicator of Spatial Association (LISA) showed that ideology similarity factor was spread uniformly and did not have spatial association. On the other hand, candidate's religiosity factor formed some patterns of spatial associations. These findings are intended to contribute the study of women's participation in politics through the application of spatial data analysis
\end{abstract}

Keywords: Female Voters, Election Behavior, Spatial Analysis

\section{Introduction}

Indonesia's democratic system provides equal space for citizens to obtain their political rights regardless their gender. To enhance the participation of women in political area, the central government has endorsed the Law on Elections No. 12/2003. This law urges the quantity of $30 \%$ as the minimum number for women representative in every levels of people council [1]. However, men still dominate the realm of Indonesian politics. This phenomenon occures not only in the capital area but also in its subordinate region. For instance, in the City of Tanjungpinang, Province of Riau Archipelago (Kepulauan Riau) where the number of female voters surpass the men voters in every general election, yet, the number of women legislators are still less than $30 \%$ in both city and province representative councils.

Considering this situation, this study aims to examine the women's political vote behavior. To simplify this study, we limit the area of research in the City of Tanjungpinang. We also set the Tanjungpinang's 2014 general election as the time frame. Primary data collected will then be visualized and analyzed in geographical framework. By this study, we expect to know what factors dominate the behavior of female voters in Tanjungpinang's general election and their relation in spatial framework. 


\section{Literature Review}

Based on our literature study, numerous researches have been carried out on the political behavior of female voters. However, it was very tough to find any particular paper that focus on utilizing spatial analysis on female voters' behavior. On the other hand, we found some valuable studies employing spatial analysis on general elections or voters [2][3][4][5]. The methods applied in those studies were concentrated on finding spatial association of measured political objects in an interconnected space.

The spatial analysis is started with a spatial association test on the variable to be measured. This is obtained by calculating the Global Moran's index (or Global Moran's I) [6]:

$$
I=\frac{n \sum_{i=1}^{n} \sum_{j=1}^{n} w_{i j}\left(x_{i}-\bar{x}\right)\left(x_{j}-\bar{x}\right)}{\sum_{i=1}^{n} \sum_{j=1}^{n} w_{i j} \sum_{i=1}^{n}\left(x_{i}-\bar{x}\right)^{2}}
$$

where $n$ is total number of observed area, $w_{i j}$ is spatial weighted parameter for the pair of area $i$ and $j$ that represents proximity, $x_{i}$ is the value of a measured variable for observed area $i, \bar{x}$ is the mean of all observed values of $x$, and $x_{j}$ is the value of observed neighbors.

Finding Local Indicator of Spatial Association (LISA) index is an important following step once we have calculated the Global Moran's I. The purpose of LISA analysis is to create clustered area based on identification of hotspots, and also to find local spatial relationship patterns. The purpose of the LISA's clustered area is to test each area and its influence on its global aspects. This index is a breakdown of Global Moran' I as described below [7]:

$$
I_{i}=\frac{\left(x_{i}-\bar{x}\right) w_{i j} \sum_{j=1}^{n}\left(x_{j}-\bar{x}\right)}{S^{2}}
$$

where $I_{i}$ is Local Moran's $I$ for the $i^{t h}$ area, and $S$ is standard deviation of measured variable in the study area.

There are several assumptions and methods combined in LISA analysis; however, this study only employs Moran's Scatterplot and significance maps.

\section{Methodology}

\subsection{Data Collection}

Primary data was obtained from questionnaire taken from April to May 2018. According to the data from Regional General Election Commission (Komisi Pemilihan Umum Daerah KPUD) of the City of Tanjungpinang, the number of female voters in the 2014 Tanjungpinang's general election was 72,162. Thus, with such number of population, the minimum population sample required was 382 [8]. Because Tanjungpinang City consists of eighteen urban villages (kelurahan), so the minimum respondents per - kelurahan are 21 people.

Before the questionnaire is distributed, it is necessary to test the reliability and validity of the questionnaire. Reliability and validity tests are carried out by determining the value of 
Cronbach's Alpha $(\alpha)$ of the measured items. This was done by conducting a pilot test on $10-$ 20 April 2018 involving 30 respondents.

The Cronbach's Alpha of female voters' behavior questionnaire showed the number of 0.878. This $\alpha$ value confirmed that the items compiled were in a good level of validity [9]. Details about the items employed can be found in Table 1.

Table 1. Female Voters' Election Behavior Questionnaire Items

\begin{tabular}{cl}
\hline Behavior & \\
\hline B1 & I will vote a candidate based on ideology similarity regardless his/her gender \\
B2 & Women have more weaknesses and limitations to be leaders compared to men \\
B3 & Handsome men have their own attraction to be chosen \\
B4 & I will vote the one I know best regardless his/her gender \\
B5 & I will vote the one from having same tribe with me regardless his/her gender \\
B6 & I will vote the one from my idol political party regardless his/her gender \\
B7 & I follow the doctrine of my religion that men are more worthy of being leaders \\
& than women \\
B8 & I will vote the most religious candidate \\
B9 & I will vote a candidate based on my husband's advice \\
B10 & I will vote a candidate based on religious leaders' advice \\
B11 & I will vote a candidate based on my admired public figures' advice \\
B12 & I will vote a candidate based on my work mates' advice \\
B13 & I will vote a candidate based on my neighbors' advice \\
B14 & I will vote a candidate based on my campus' advice \\
B15 & There is no guarantee that if I choose a female candidate, she will fight for my \\
& civilian rights \\
B16 & I will vote the one having family relationship with me \\
B17 & I am not interested to female candidates because it has proven that they fail \\
& when leading
\end{tabular}

\subsection{Spatial analysis methods}

Spatial analysis is carried out through several stages as stated below:

1. Display spatial visualization of the dominant behaviors in Tanjungpinang's kelurahan by using QGIS software [10]

2. Select the most dominant behavior item to be analyzed.

3. Calculate Global Moran's I to see whether there is a spatial association in the designed area.

4. Conduct LISA analysis to find out if there is an area clustering and find patterns of local area based spatial relationships. This is performed by making a Moran's scatter plot, calculating local Moran's index, and drawing significant maps. Steps 3-4 are carried out by using Geoda software [11]. 


\section{Results and Discussion}

Figure 1 describes dominant (kelurahan based) - female voters' behavior in Tanjungpinang's 2014 election. Indexes A - R in Figure 1 represent Kelurahan Air Raja, Batu IX, Bukit Cermin, Dompak, Kampung Bugis, Kampung Bulang, Kemboja, Melayu Kota Piring, Penyengat, Pinang Kencana, Sei Jang, Senggarang, Tanjung Ayun Sakti, Tanjung Unggat, Tanjungpinang Barat, Tanjungpinang Kota, Tanjungpinang Timur, respectively. Detail about each kelurahan's behavior value can be found in [12].

Figure 1 shows that behavior number 1 (B1) symbolized in red color and number 8 (B8) symbolized in green color contests to dominate the area of kelurahan in Tanjungpinang. From Figure 1, it can be seen that B1 is dominant in nine kelurahans whereas B8 in six kelurahans. Three kelurahans (Penyengat, Sei Jang, and Senggarang) are competing between them (violet color). Thus, the spatial analysis in this paper will be focused on B1 and B8.

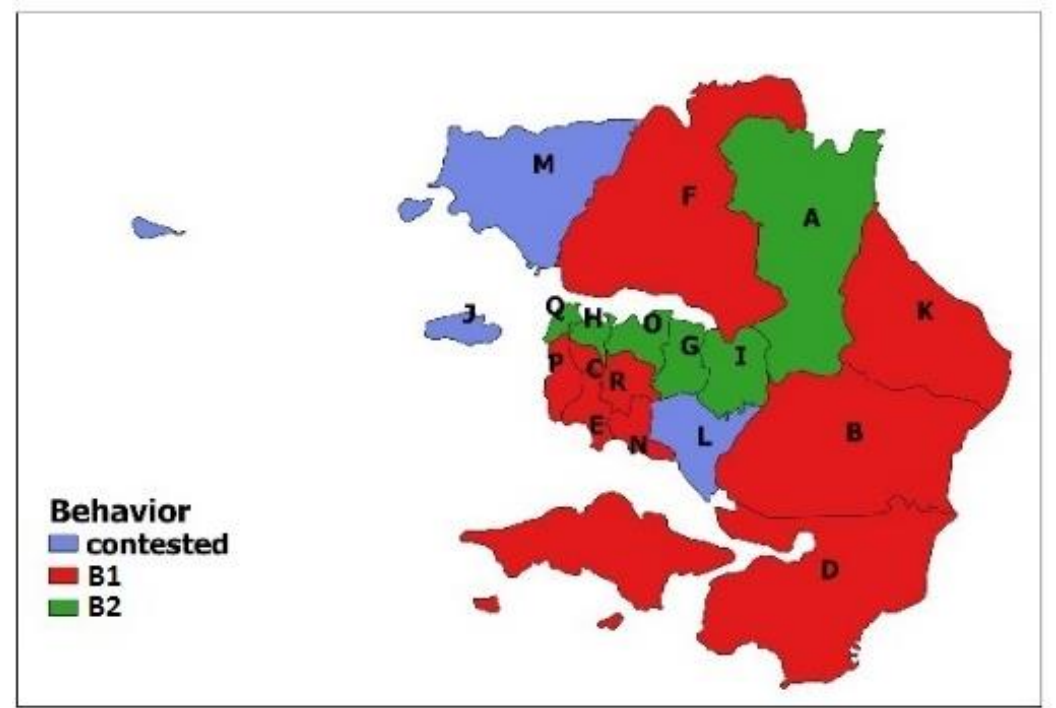

Figure 1. Spatial Pattern of Female Voters' Election Behavior in Tanjungpinang's Kelurahan

The calculation of Global Moran's $I$ of B1 and B8 are presented in Table 2. Moran's $I$ values vary from -1 to 1 . The more Moran's $I$ value tends to 0 , the weaker spatial association happens. Positive Moran's $I$ value indicates positive correlation which means the proximity area is identical. On the other hand, the negative Moran's $I$ value indicates a negative spatial association, which imply adjacent area is not similar and forms a visual pattern like a chessboard. Table 2 shows that B1 indicates a positive spatial associations and B8 has a negative correlation. However, from the statistical test of $P$ value shows that only $\mathrm{B} 8$ has a $P$ value smaller than 0.05 . This reveals that spatial association of B8 is statistically significant at $95 \%$ of confidence level. This finding confirms that B8 has a spatial association while B1 does not. 
Table 2. Global Moran's $I$ of B1 and B8

\begin{tabular}{lll}
\hline Factor & Moran' $I$ & $P$ value \\
\hline F1 & 0.1533 & 0.1160 \\
F8 & -0.3177 & 0.0360 \\
\hline
\end{tabular}

Figures 2 and 3 show the LISA analysis of B1 and B8, respectively. It could be seen from Figure 2 that six kelurahan located in high-high quadrant (I (HH)), 4 in high low quadrant (II (HL)), 4 in low-low quadrant (III (LL)), and 4 in low-high quadrant (IV (LH)). However, there are no significant spatial association of kelurahan for all quadrants of B1. On the other hand, Figure 3 shows that there are significant associations of B8 in HL quadrant which centered in Dompak and in LL quadrant which is pointed in Kampung Baru.

\begin{tabular}{|c|c|c|}
\hline IV (LH) & I (HH) & \\
\hline $\begin{array}{c}\text { Penyengat, } \\
\text { Melayu Kota Piring, } \\
\text { Air Raja, } \\
\text { Tanjungpinang Timur }\end{array}$ & $\begin{array}{c}\text { Tanjung Ayun Sakti, } \\
\text { Senggarang, } \\
\text { Sei Jang, } \\
\text { Pinang Kencana, } \\
\text { Dompak, } \\
\text { Batu IX, } \\
\text { Kampung Baru }\end{array}$ & $\begin{array}{l}\text { LISA Cluster Map of F1 } \\
\square \text { Not Significant (17) } \\
\text { High-High (0) } \\
\text { Low-Low (0) } \\
\text { Low-High (0) } \\
\square \text { High-Low (0) } \\
\text { Neighborless (1) }\end{array}$ \\
\hline $\begin{array}{l}\text { Kampung Bulang, } \\
\text { Kemboja, } \\
\text { Tanjung Pinang Barat, } \\
\text { Tanjungpinang Kota }\end{array}$ & $\begin{array}{l}\text { Kampung Bugis, } \\
\text { Bukit Cermin, } \\
\text { Tanjung Unggat } \\
\text { Kampung Baru }\end{array}$ & \\
\hline III (LL) & II (HL) & \\
\hline
\end{tabular}

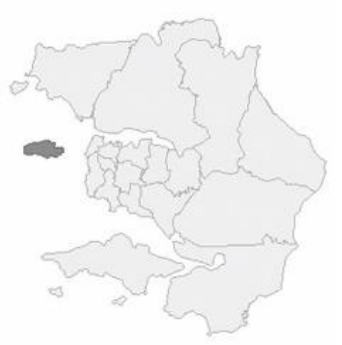

Figure 2. Moran's Scatter Plot (left) and LISA Cluster Map (Right) for B1 Behavior
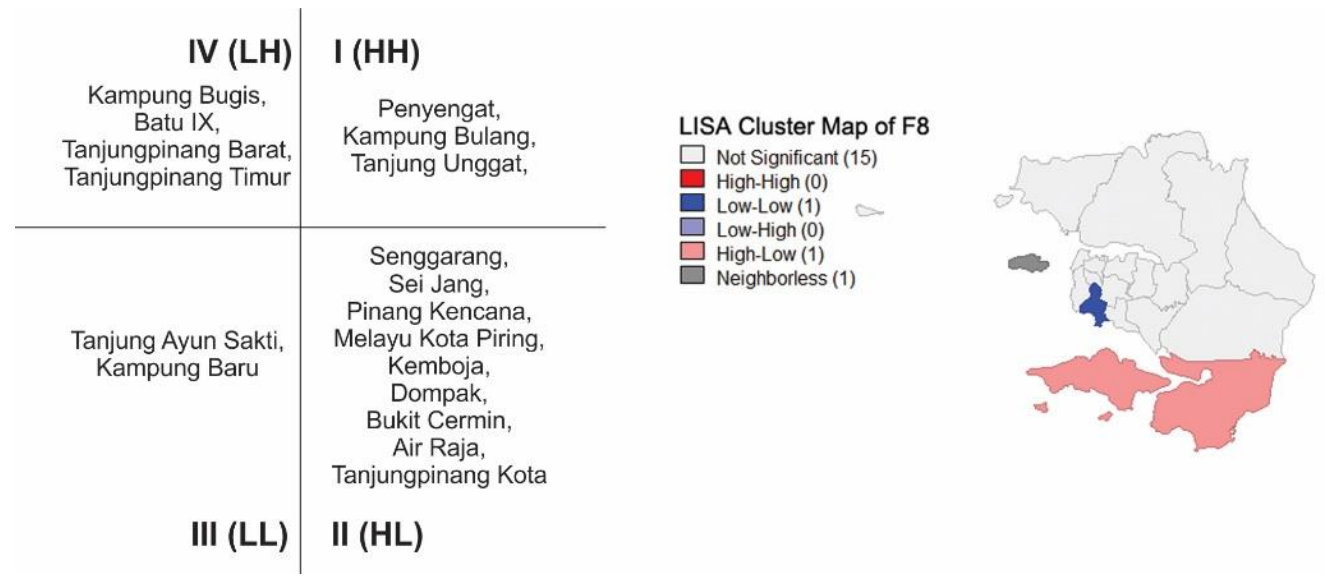

Figure 3. Moran's Scatter Plot (left) and LISA Cluster Map (Right) for B8 Behavior 


\section{Conclusion}

From this study we conclude that the most important factors for female voter's election behavior in Tanjungpinang are the similarity of ideology (B1) and candidate religiosity (B8). The spatial analysis of Global Moran's I and LISA indexes of both factors showed that there are no spatial association for B1 behavor while B8 has.

\section{Acknowledgments}

Our sincere gratitude to the Women's and Children's Empowerment Agency, Province of Kepulauan Riau, Indonesia for funding this study.

\section{References}

[1] Hillman, B.: The limits of gender quotas: women's parliamentary representation in Indonesia, Journal of Contemporary Asia, 48(2), 322-338, doi: 10.1080/00472336.2017.1368092 (2017)

[2] Lawal, O.: Geographical pattern and structure of the 2011 and 2015 Nigeria presidential election, African Geographical Review, 1-20, doi: 10.1080/19376812.2017.1284007 (2017)

[3] Yandri, P.: The political geography of voters and political participation: evidence from local election in suburban Indonesia. Indonesian Journal of Geography, 49(1), 57-64, doi:10.22146/ijg.11315 (2017)

[4] Ozen, I. C., Kalkan, K. O.: Spatial analysis of contemporary Turkish elections: a comprehensive approach, Turkish Studies, 18:2, 358-377, doi: 10.1080/14683849.2016.1259576 (2017)

[5] Maškarinec, P.: A spatial analysis of Czech parliamentary elections, 2006-2013, Europe-Asia Studies, 69:3, 426-457, doi: 10.1080/09668136.2017.1313962 (2017)

[6] Anselin, L.: Spatial econometrics: Methods and models. Kluwer Academic, Dordrecht (1988)

[7] Anselin, L.: Local indicators of spatial association-LISA. Geographical Analysis 27(2): 93-115, doi:10.1111/j.1538-4632.1995.tb00338.x (1995)

[8] Krejcie, R. V., Morgan, D. W.: Determining sample size for research activities. Educational and Psychological Measurement 30(3), 607-610, doi:10.1177/001316447003000308 (1970)

[9] Sekaran, U., Bougie, R.: Research methods for business: A Skill Building Approach, $7^{\text {th }}$ ed. Wiley , Chichester (2016)

[10] QGIS Development Team: QGIS Geographic Information System. Open Source Geospatial Foundation. URL http://qgis.osgeo.org (2018)

[11] Anselin, L., Sergio J. R.: Modern Spatial Econometrics in Practice, a Guide to Geoda, Geodaspace and Pysal. GeoDa Press, Chicago (2014)

[12] Muhammad, A. S., Gusrizal, Sucipta, P. R., Wahyudi, R., Misni: Political Orientation of Female Voters in General Elections (Case Study in the $2014^{\text {th }}$ General Election in Tanjungpinang City) (in bahasa). Women's and Children's Empowerment Agency of Kepulauan Riau Province, Tanjungpinang (2018) 